\title{
Biochemical, microbiological and technological characteristics of type II sourdoughs produced with lactic acid bacteria single-strains
}

\section{Características bioquímicas, microbiológicas e tecnológicas de sourdoughs tipo II produzidos com uma única cepa de bactéria ácido lática}

\author{
Francieli Begnini Siepmann ${ }^{1 *}$; Beatriz Sousa de Almeida ${ }^{2}$; Tatiane Aparecida \\ Gomes $^{3}$; Nina Waszczynskyj; ; Michele Rigon Spier ${ }^{4}$
}

\section{Highlights}

Type Il sourdough fermentation by eleven different lactic acid bacteria (LAB).

The acetic acid decreases the autochthonous yeasts.

The LAB influences in the sourdough volatile profile.

Lactobacillus reuteri produces a sourdough with good technological characteristics.

\begin{abstract}
The interplay between biochemical characteristics and the generation of volatile compounds in 11 type II sourdough fermented by single strains of lactic acid bacteria (LAB) was studied. Samples were collected at $0,6,9,12,15,18$ and $24 \mathrm{~h}$ for analyses of microbial growth, $\mathrm{pH}$, titratable acidity and $\mathrm{CO}_{2}$ production. During the first $12 \mathrm{~h}$, the LABs entered the stationary phase, and the formation of organic and carboxyl acids, alcohols, and esters were observed. Although acidity is an important characteristic of sourdough, in this work increasing the acetic acid content decreased yeast growth and the $\mathrm{CO}_{2}$ retention capacity of the doughs. The main carbohydrate consumed by autochthonous yeast was influenced by the LAB added (homo-or heterofermentative), as observed by correlation analysis. Maltose and glucose showed a strong and negative correlation with the yeast cell density in the dough fermented by homo and heterofermentative $\mathrm{LAB}$, respectively. Moreover, LAB had an important effect on the aromatic profile, being the alcohols, aldehydes, alkanes, organics acids and esters mainly groups characterized. Altogether, 100 different

1 Ph.D Student of the Post Graduate Program in Food Engineering at Universidade Federal do Paraná, UFPR, Curitiba, PR, Brazil. E-mail: franbegnini@gmail.com

2 Graduate Student of the Chemical Engineering Program at UFPR, Curitiba, PR, Brazil. E-mail: bia123sousa123@ gmail.com

3 Ph.DStudent of the Post Graduate Program in Food Engineering atUFPR, Curitiba, PR, Brazil. E-mail:tatianeapgomes@ gmail.com

${ }^{4}$ Profs. Ph.D of the Post Graduate Program in Food Engineering, Technology Sector, Chemical Engineering Department at UFPR, Curitiba, PR, Brazil. E-mail: nina.ninawas@gmail.com; spier@ufpr.br

* Author for correspondence
\end{abstract}

Received: Aug. 17, 2021 - Approved: Dec. 07, 2021 
volatile compounds were identified; however, each dough had a different volatile profile. This study shows, for the first time, the influence of a single strain of $L A B$ on the characteristics of type II sourdough.

Key words: HS-SPME. Volatile compounds. Starter culture. Lactobacillus reuteri.

\section{Resumo}

As características bioquímicas e a produção de compostos voláteis em 11 diferentes sourdough tipo II produzido com uma única cepa de bactérias do ácido láctico (BAL) em foi estudada. As amostras foram coletadas às $0,6,9,12,15,18$ e 24 h para análises de crescimento microbiano, pH, acidez titulável e produção de $\mathrm{CO}_{2}$. Durante as primeiras $12 \mathrm{~h}$, as BAL entraram em fase estacionária, sendo observada a formação de ácidos orgânicos e carboxílicos, álcoois e ésteres. Embora a acidez seja uma característica importante do sourdough, neste trabalho o aumento do teor de ácido acético diminuiu o crescimento das leveduras e a capacidade de retenção de $\mathrm{CO}_{2}$ nas massas. Também foi observado que o principal carboidrato consumido pelas leveduras autóctones foi influenciado pela BAL adicionada (homo ou heterofermentativas), conforme observado pela análise de correlação. A maltose e a glicose apresentaram uma correlação forte e negativa com a densidade celular de levedura na massa fermentada por BAL homo e heterofermentativas, respectivamente. Além disso, a BAL teve efeito importante no perfil aromático, sendo os álcoois, aldeídos, alcanos, ácidos orgânicos e ésteres os principais compostos caracterizados. Ao todo, foram identificados 100 compostos voláteis diferentes; no entanto, cada massa apresentou um perfil volátil diferente. Este estudo mostra, pela primeira vez, a influência de uma única cepa de BAL nas características de sourdough tipo II.

Palavras-chave: HS-SPME. Compostos voláteis. Culturas iniciadoras. Lactobacillus reuteri.

\section{Introduction}

The consumption of bread and bakery products is directly affected by their freshness, taste and health benefits (Sajdakowska, Gebski, Zakowska-Biemans, \& Jezewska-Zychowicz, 2019). One of the ways to increase the quality of these products is with the use of sourdough, a dough fermented by lactic acid bacteria (LAB) and yeasts.

Depending on the production method, sourdough can be classified into four different types. Type I sourdough is known for slow and spontaneous fermentation by the microbiota present in the flour, water and air. In type II sourdough, fermentation is faster (15-24 h) due to addition of a starter culture (LAB with or without yeast). Type III sourdough is produced by dehydration of type II sourdough. Finally, type IV or mixed sourdough is characterized by the addition of starter culture or inoculum but fermented for a longer time (Hammes \& Gänzle, 1998; Nionelli et al., 2014; Siepmann, Ripari, Waszczynskyj, \& Spier, 2018).

Type I sourdough is mostly produced by artisanal bakeries, and each dough produced has unique characteristics, due to variation in the autochthone microbiota, substrate and production process (Siepmann et al., 2018). Due to this diversification, this type of sourdough is the most studied to date. However, for industrial-scale production, the use of an adapted starter culture and the standardization of the process and 
consequently of the products are essential and made possible through the use of type II sourdough (Reale et al., 2019).

However, for correct selection of the starter culture, it is important to consider sourdough as a complex ecosystem in which LAB and yeasts can act synergistically or antagonistically due to substrate competition (De Vuyst, Vrancken, Ravyts, Rimaux, \& Weckx, 2009). Members of the genus Lactobacillus are classified as obligate homofermentative, heterofermentative or facultative heterofermentative. Homofermentative LAB ferment only hexoses through the EMP (Embden-Meyerhof-Parnas) pathway, producing lactic acid. Obligate heterofermentative LAB ferment both hexoses and pentoses through the 6-PG/ PK (6-phosphogluconate/phosphoketolase) pathway, releasing equimolar concentrations of lactic acid, acetic acid and/or ethanol and $\mathrm{CO}_{2}$, while the facultative heterofermentative $L A B$ ferment both hexoses through the EMP pathway, and pentoses and gluconate through the 6-PG/PK pathway (Hammes \& Vogel, 1995).

Due to the production of lactic and acetic acids, dough acidification and consequently $\mathrm{pH}$ reduction occurs, causing starch hydrolysis, gluten degradation and the production of a dough with greater extensibility and internal humidity. Acid production favours the growth of yeast, increasing the volatile compound concentration (Clarke, Schober, Dockery, O'Sullivan, \& Arendt, 2004; Corsetti, 2013), $\mathrm{CO}_{2}$ productionand shelf-life (Demirbaş, Ispirli, Kurnaz, Yilmaz, \& Dertli, 2017; Gänzle, Ehmann, \& Hammes, 1998; Manini et al., 2016; Poutanen, Flander, \& Katina, 2009).
However, excess acid production is undesirable since it may inhibit the growth of autochthonous yeasts and may cause excessive gluten hydrolysis (Corsetti et al., 1998). Therefore, the selection of LABs as starter cultures is an essential step in the production of a type II sourdough with high technological quality.

Considering the importance of LAB in the fermentation of type II sourdough, this work aimed to evaluate the impact of eleven LAB (Lactobacillus acidophilus, Lactobacillus amylovorus, Lactobacillus brevis, Lactobacillus bulgaricus, Lactobacillus fermentum, Lactobacillus jhonsonii, Lactobacillus plantarum, Lactobacillus reuteri, Lactobacillus sakei, Pediococcus acidilactici and Pediococcus pentosaceus) in the volatile profile and microbiological, biochemical and technological parameters of whole-wheat type II sourdough.

\section{Materials and Methods}

\section{Starter culture}

The $L A B$ evaluated as starter cultures were L. amilovorus (NRRL B-4540), L. brevis (NRRL B-4527), L. fermentum (NRRL B-1932), L. jhonsonii (NRRL B-2178), L. reuteri (NRRL B-14171), L. sakei (NRRL B-1917) and P. acidilactici (NRRL B-14958), donated by ARS Culture Collection (NRRL), L. bulgaricus (CCT0366) donated by André Tosello Institution and $L$. plantarum and $P$. pentosaceus isolated from Brazilian whole-wheat flour. The LABs were cultivated for $48 \mathrm{~h}$ at $35^{\circ} \mathrm{C}$ on modified Man-Rogosa-Sharpe broth (MRSm) (10 g peptone, $8 \mathrm{~g}$ meat extract, $4 \mathrm{~g}$ yeast extract, 
$10 \mathrm{~g}$ glucose, $10 \mathrm{~g}$ maltose, $1 \mathrm{~g}$ tween $80.2 \mathrm{~g}$ dibasic phosphate, $5 \mathrm{~g}$ sodium acetate, $2 \mathrm{~g}$ ammonium citrate, $0.2 \mathrm{~g}$ magnesium sulphate and $0.05 \mathrm{~g}$ manganese sulphate).

\section{Sourdough preparation}

The LABs were centrifuged at $5000 \times$ $g$ for 5 min, washed twice in Ringer's solution (Oxoid) and re-suspended in the same solution. The starter culture was added to a final concentration of around $10^{5} \mathrm{CFU} \mathrm{g}^{-1}$ to the dough.

The dough $(1 \mathrm{~kg})$ was prepared with $500 \mathrm{~g}$ of commercial whole-wheat flour $(72.8 \pm$ 0.05 total carbohydrates; $12.7 \pm 0.14$ protein; $10.7 \pm 0.27$ moisture; $2.1 \pm 0.03$ lipid and 1.5 $\pm 0.18 \mathrm{ash})$ and $500 \mathrm{~g}$ sterile distilled water (dough yield of 200 DY $=$ dough weight $\times 100$ / flour weight). The dough was fermented at 35 ${ }^{\circ} \mathrm{C}$ for $24 \mathrm{~h}$ in a 2-L glass beaker covered with plastic film. These conditions were determined in previous tests (results not shown).

\section{Sourdough analyses}

Samples were collected at 0, 6, 9, 12, 15,18 and $24 \mathrm{~h}$ of fermentation for analyses in triplicate of $\mathrm{pH}$, titratable acidity (TTA) and plate counts of LAB and yeast. At the same time points, $\mathrm{CO}_{2}$ production was evaluated. The analyses of organic acids (acetic and lactic acids) and soluble carbohydrate (maltose, sucrose, glucose, fructose and starch) quantification were carried out in triplicate, and the samples were collected every $6 \mathrm{~h}$ of fermentation. The fermentation quotient (FQ) was determined as the molar ratio between lactic and acetic acids.
pH and TTA analyses

The $\mathrm{pH}$ value of each dough was determined with a $\mathrm{pH}$ meter (Model Luca-210, MS Tecnopon, São Paulo, Brazil) by diluting 10 $\mathrm{g}$ of the sample in $90 \mathrm{~mL}$ distilled water. The same sample was utilized for total titratable acidity (TTA) determination, expressed as the amount ( $\mathrm{mL}$ ) of $0.1 \mathrm{~N} \mathrm{NaOH}$ needed to reach a $\mathrm{pH}$ value of 8.5.

\section{$\mathrm{CO}_{2}$ production}

The $\mathrm{CO}_{2}$ production, as a result of dough leavening and expansion, was indirectly measured using the methodology cited by Vernon-Carter (Vernon-Carter, Garcia-Diaz, Reyes, Carillo-Navas, \& Alvarez-Ramirez, 2017) with modifications, recording the volume of each variation (30 g) in a 100-mL graduated vessel. The results are presented as the percentage change in relation to the initial volume.

\section{Microbiological analyses}

For plate counts, $10 \mathrm{~g}$ sourdough was diluted in $90 \mathrm{~mL}$ of sterile peptone water $(1 \%$ [wt/vol] of peptone and $0.9 \%$ [wt/vol] $\mathrm{NaCl}$ ), homogenized in a stomacher (BagMixer $^{\circledR}$ 400; Interscience, Saint Nom, France) for 2 min at maximum speed and subjected to serial decimal dilutions. For LAB counts, MRS medium supplemented with an antifungal agent (ciclopiroxolamina $10 \mathrm{mg} \mathrm{mL}^{-1}$ ) was used and incubated in an anaerobic jar at $35^{\circ} \mathrm{C}$ for 48 h. For total yeast counts, Dichloran Rose Bengal Chloramphenicol (DRBC) medium with $1 \mathrm{mg} / \mathrm{L}$ chloramphenicol (Himedia, India) was used and incubated aerobically at $28{ }^{\circ} \mathrm{C}$ for 48-72 h. 
2.3.4 Quantification of organic acids and soluble carbohydrates

Organic acids and soluble carbohydrates (maltose, glucose and fructose) were quantified by Ultra Performance Liquid Chromatography (UPLC; Waters, model Acquity, Brazil) using the refractive index (RI), according to the methodology described by Siepmann et al., 2019. The molar ratio between lactic and acetic acids was also determined since it represents an important technological parameter, known as the fermentation quotient (FQ), that affects the sourdough aroma profile (Corsetti, 2013). Starch quantification was performed according to Fuwa (1954).

\section{Volatile compounds}

Volatile compounds were analysed using gas chromatography coupled to mass spectrometry HS-SPME (Head-Space Solid Phase Micro-Extraction; Shimadzu, model TQ8040, Japan) according to the methodology described by Siepmann et al., 2019. The analyses were realized with 12 and $24 \mathrm{~h}$ of fermentation, and only the last ones were presented.

\section{Statistical analysis}

Replicates were performed for each analysis, and the results were expressed as mean \pm SD (standard deviation). The results were analysed using analysis of variance (ANOVA) and Tukey's post hoc test with a $95 \%$ confidence level ( $p \leq 0.05)$. The Pearson correlation between the results of yeast concentration and carbohydrates (maltose, glucose and fructose) and organic acids (acetic and lactic acids) were realized in the doughs with $24 \mathrm{~h}$ of fermentation using Statistica software 7.0 for Windows (StatSoft, United States).

\section{Results and Discussion}

\section{Microbial dough results}

The initial $L A B$ inoculums varied from 4.9 to $5.7 \log C F U ~ g^{-1}$ (Figure 1), reaching a wide range of cell densities, with values from 7.9 (L. jhonsonii, Figure 1f) to $9.4 \log$ CFU g ${ }^{-1}$ (L. acidophilus and L. amylovorus, Figure 1a and Figure $1 \mathrm{~b}$ ) at the end of the fermentative process. In the first $12 \mathrm{~h}$ of fermentation, all LABs achieved the stationary growth phase, and a marked decrease in the $\mathrm{pH}$ of the doughs was observed (from 6.20-6.42 to 3.61-4.40); already between 12 and $24 \mathrm{~h}$, the $\mathrm{pH}$ had a small variation, achieving values from 3.55 to 3.78 (Table 1). These values were within the ideal range for sourdough (between 3.55 and 4.50), indicating good development of all doughs (Esteve et al., 1994). 

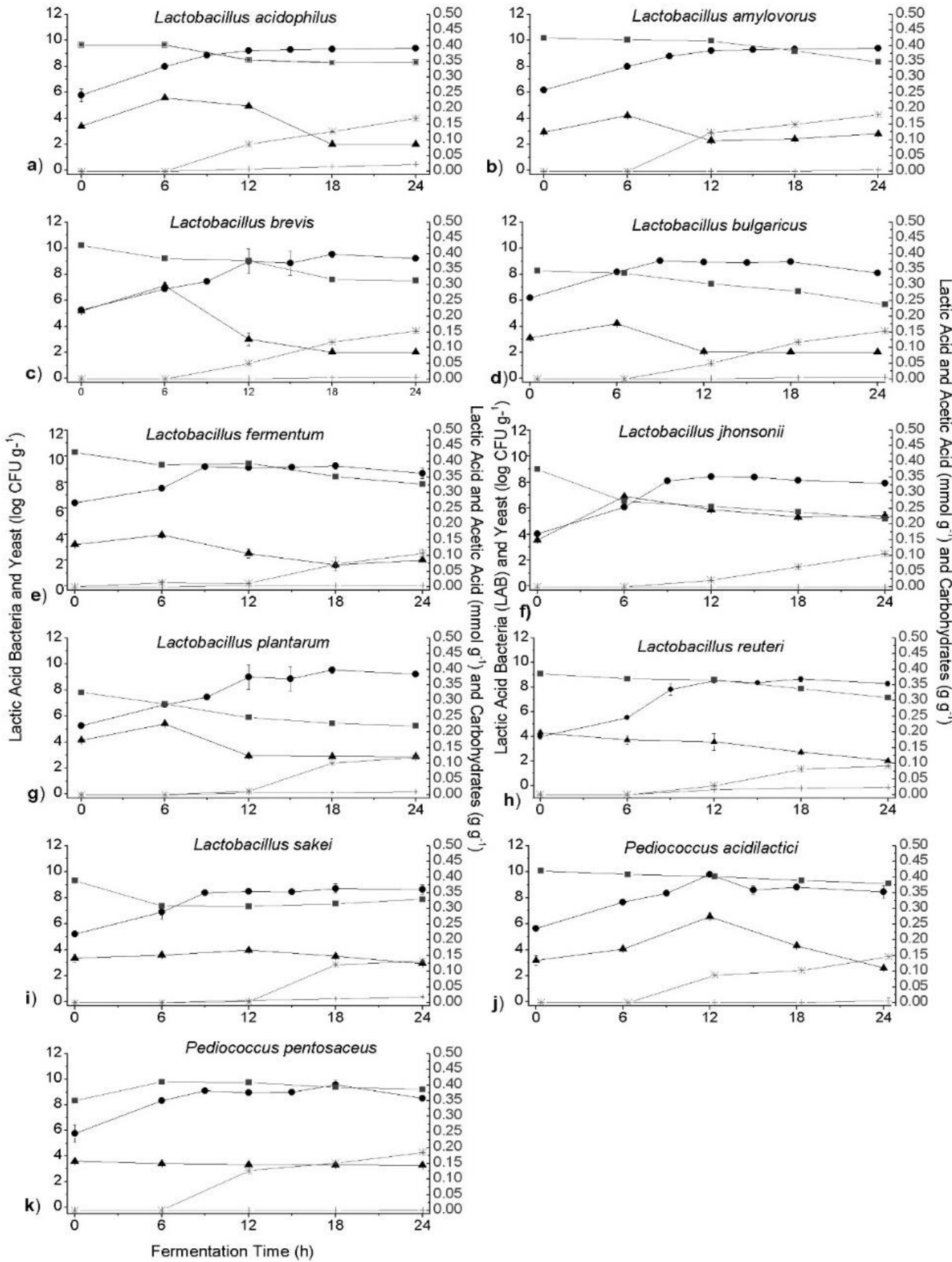

- LAB - Yeast * Lactic Acid + Acetic Acid - - Carbohydrates (starch+glucose+fructose+maltose)

Figure 1. Growth kinetics of lactic acid bacteria and yeast in type II sourdough during $24 \mathrm{~h}$ fermentation. 


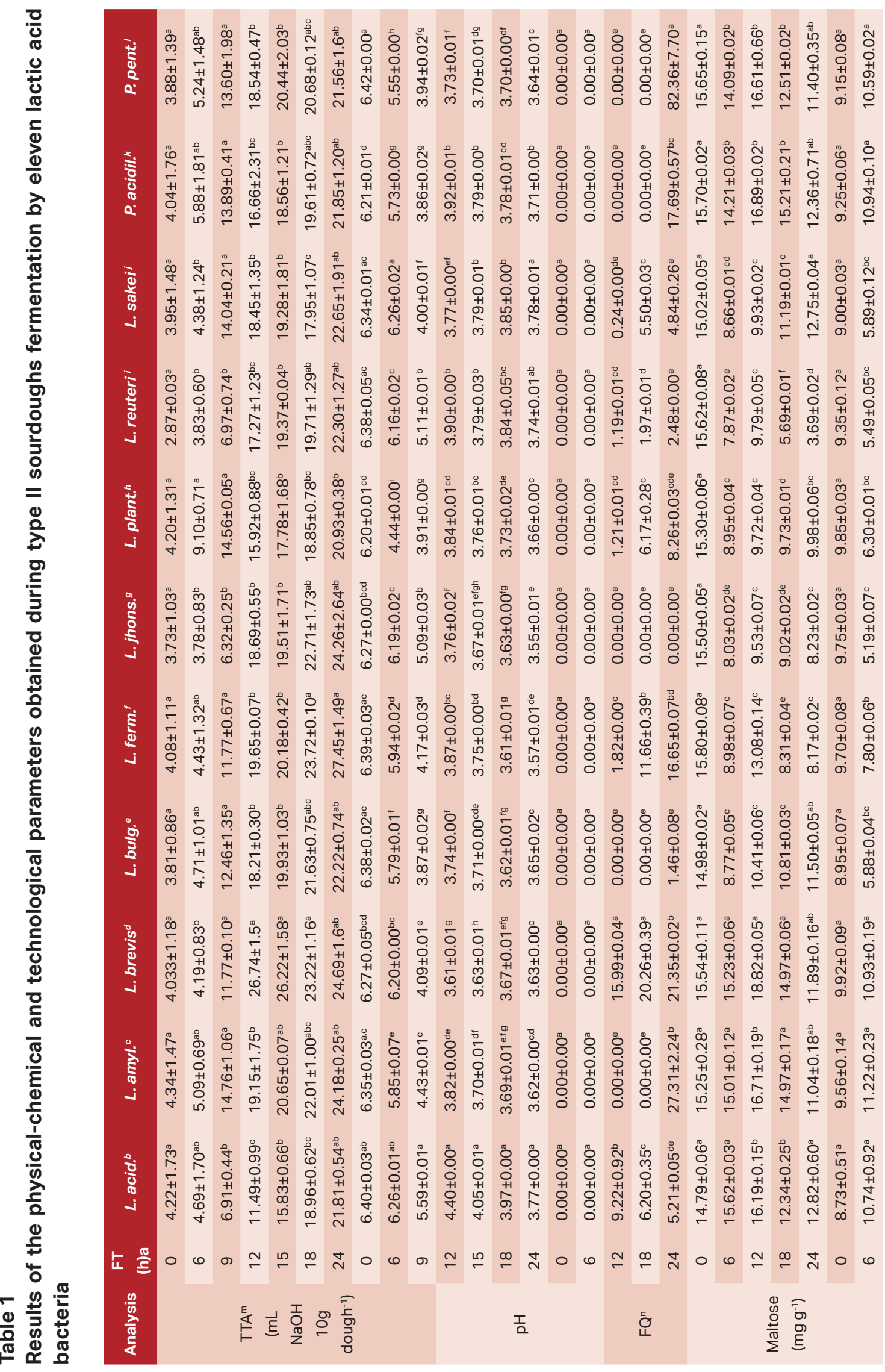




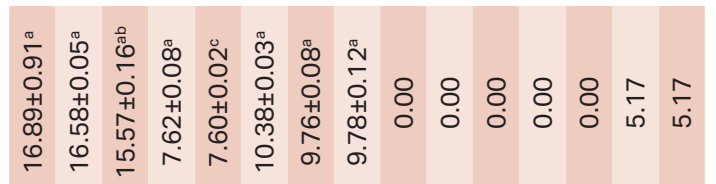

โุ

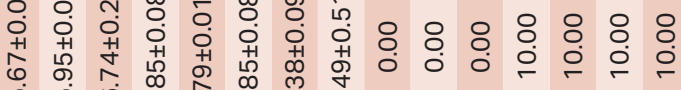

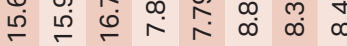

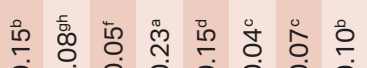

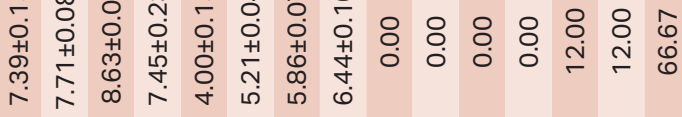

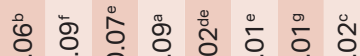

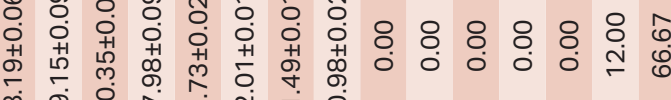

क

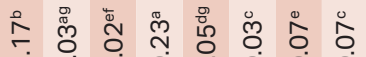

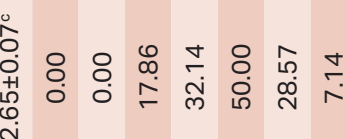

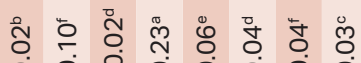

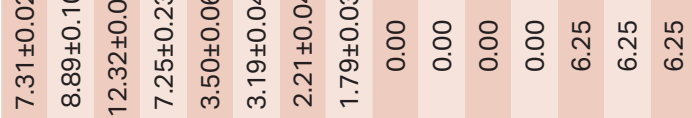

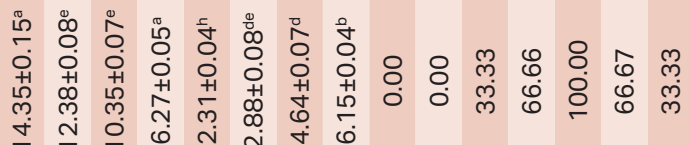

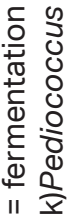

点

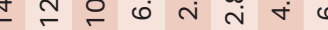

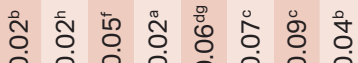

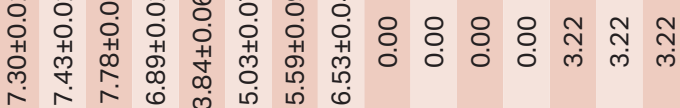

๙ิن

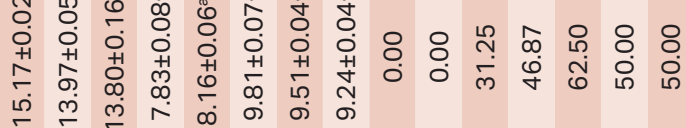

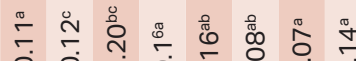

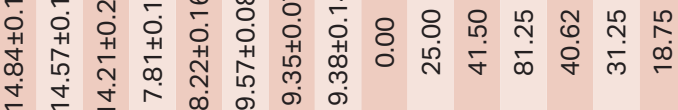

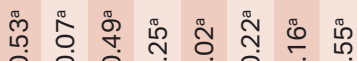

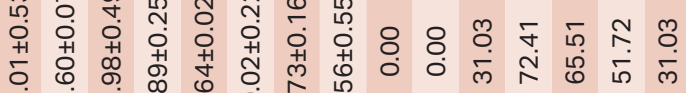

它

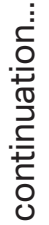

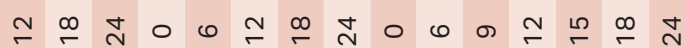

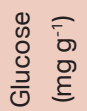

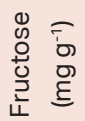

$8^{\circ} \stackrel{\circ}{\circ} \frac{0}{2} \div$

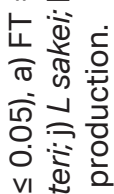

웡

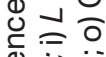

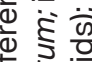

要

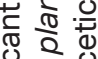

壳

क :

过

苟

을

응

ते हो

ट

$\therefore$ j

उ के

空

(1)

है

$\stackrel{1}{\mp}$ 음

$\subseteq$ is

काँ ऐे

ब․

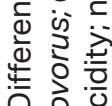

*

ธू है

元过苋

व

을

응 웡

के

$+10$

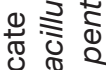

음

吾过

की 
ThepHdecreasesduetotheproduction of organic acids such as acetic and/or lactic acid, through the conversion of hexose and/ or pentose by LAB (Hammes \& Gänzle, 1998). L. fermentum was the bacterium that started lactic acid production in the dough, with a concentration of $0.13 \mathrm{mmol} \mathrm{g}^{-1}$ in $6 \mathrm{~h}$ (Figure 1e). Moreover, L. sakei (Figure 1i) showed the slowest fermentation, presenting no lactic acid for up to $18 \mathrm{~h}$ of fermentation. The dough fermented by $L$. reuteri had the lowest lactic acid concentration $\left(0.09152 \mathrm{mmol} \mathrm{g}^{-1}\right)$ and the highest acetic acid concentration $(0.025$ $\mathrm{mmol} \mathrm{g}^{-1}$ ). This $L A B$ is commonly found in type II sourdough and is characterized as a heterofermentative and acid-tolerant bacterium, justifying its growth, even in acidic dough (Hammes \& Gänzle, 1998; Huys, Daniel, \& De Vuyst, 2013).

Acetic acid production did not only occur in the dough fermented by L. johnsonii (Figure 1f); the other homofermentative LAB (such as $L$. acidophilus, L. amylovorus, $L$. bulgaricus, $P$. acidilactici and $P$. pentosaceus) produced doughs with final concentrations from 0.001 to $0.021 \mathrm{mmol} \mathrm{g}^{-1}$. The acetic acid production in these doughs might be related to the presence of other flour bacteria such as Acetobactersp. (Ripari, Gänzle \& Berardi, 2016) and yeast species that produce acetic acid, like Candida krusei and Wickerhamomyces anomalus (Swiegers, Bartowscky, Henscke, \& Pretorius, 2005).

When the results of correlation between the acetic acid concentration in the doughs with heterofermentative and heterofermentative facultative LABs (L. brevis,

$L$. fermentum, $L$. plantarum, $L$. reuteri and L. sakei) and yeast growth were evaluated, a positive correlation was observed $(r=$
0.79), showing that the increase in the concentration of this acid aided yeast growth. However, the opposite result was obtained for the doughs with homofermentative LAB (L. acidophilus, L. amylovorus, $L$. bulgaricus, $L$. jhonsonii, $P$. acidilactici and $P$. pentosaceus), which presented a negative correlation $(r=$ -0.61), indicating that the increase in acetic acid concentration negatively affected the final concentration of yeasts. This result is strongly evidenced by the dough fermented by $L$. jhonsonni and $L$. acidophilus. The former presented the absence of acetic acid and higher yeast cell density in $24 \mathrm{~h}$ of fermentation (5.41 log CFU g ${ }^{-1}$ ). However, the latter presented a higher acetic acid concentration and a yeast concentration lower than the detectable limit $\left(2.00 \mathrm{log} \mathrm{CFU} \mathrm{g}^{-1}\right)$. For the lactic acid concentration, no significant correlation with yeast growth was obtained. In sourdough, the molar ratio between the lactic and acetic acid concentrations is known as the Fermentation Quotient (FQ), which is affected by the carbohydrate available in the flour, fermentation temperature, oxygen concentration and the microbiota. The dough fermented by $P$. pentosaceus presented the highest FQ (82.36) (Table 1), which was statistically different $(p \leq 0.05)$ from that of the remaining doughs. This result is due to the high lactic acid and low acetic acid concentrations. Regarding L. jhonsonii, it was not possible to calculate the FQ due to the absence of acetic acid. The recommended optimal range of $F Q$ is between 2.0 and 2.7 (Hammes \& Gänzle, 1998), a value obtained only from the dough made with L. reuteri. Normally, sourdoughs are produced with a starter culture, resulting a more suitable acidification and aromatization of the sourdough (Decock \& Cappelle, 2005). However, even with starter culture addition 
it is possible obtain an $\mathrm{FQ}$ value above the recommended level, as observed in sourdough enriched with insect $(F Q=3.22$ to 4.46) (Gaglio et al., 2021) and in chickpea sourdough after $48 \mathrm{~h}$ and $72 \mathrm{~h}$ of fermentation (FQ 48 h = 11.6 FQ 72 h = 18.1) (Lazo-Vélez, Garzon, Guardado-Félix, Serna-Saldivar, \& Rosell, 2021). The high FQ value highlights the imbalance in the lactic acid acetic acid concentrations, which may interfere in the microbiota, the technological (texture, volume) and sensory (aroma and taste) characteristics reinforced the need for the addition of homoand heterofermentative LABs together.

In addition to lactic and acetic acids, other organic acids are synthesised in sourdough during the fermentation process, the total value being measured by TTA analysis (Cappelle, Guylaine, \& Gänzle, 2013). In all doughs evaluated, the TTA value showed an increase during the first $12 \mathrm{~h}$ of fermentation (Table 1). In the same period, the beginning of the LAB stationary growth phase and the growth decline phase for the yeast was observed (Figure 1). In addition, a significative $\mathrm{pH}$ reduction was verified along with the increase in the acetic and lactic acid concentrations.

In the first $12 \mathrm{~h}$ of the fermentation process, the TTA values (Table 1) showed the greatest increase, reaching values between 11.49 (L. acidophilus) and $26.74 \mathrm{~mL}$ $\mathrm{NaOH} 10 \mathrm{~g} \mathrm{dough}^{-1}$ (L. brevis). At the end of the fermentative process $(24 \mathrm{~h})$, the range obtained was from 20.93 (L. plantarum) to

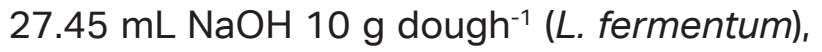
which were statistically different one from another $(p \leq 0.05)$. These TTA values are higher than reported by Alfonzo et al. (2017) and Wang et al. (2021), who observed values of (2.0 to $5.6 \mathrm{~mL} \mathrm{NaOH} 10 \mathrm{~g} \mathrm{dough}^{-1}$ ) and (0.71 to $11.06 \mathrm{~mL} \mathrm{NaOH} 10 \mathrm{~g}$ dough-1), respectively. The high acidity of the doughs (TTA, and $\mathrm{FQ}$ values) may be a result of the single fermentation and excessive fermentation time. These results might have contributed to the decline in the yeast cell density from 12 $\mathrm{h}$ of fermentation since the yeasts tolerate a low $\mathrm{pH}$ range, but not high concentrations of organic acids, as acetic and lactic acids (Narendranath, Thomas 2001). In Table 1 and Figure 1, it is important to highlight that in 12 $\mathrm{h}$ of fermentation, the dough with the highest TTA value (L. brevis) had a yeast concentration lower than $<2.00 \log \mathrm{CFU} \mathrm{g}{ }^{-1}$, even though it was the dough with the highest initial yeast value (5.00 log $\mathrm{CFUg}^{-1}$ ). The doughs with $L$. acidophilus, $L$. bulgaricus and $L$. fermentum also showed a yeast concentration $<2.00$ $\log$ CFU g ${ }^{-1}$ in $24 \mathrm{~h}$. These results may be due to organic acid concentration, substrate competition or the production of some yeast inhibitation product. In the remaining doughs, the yeast cell density varied from 2.02 to 5.40 $\log$ CFU g ${ }^{-1}$ at the end of the fermentation process.

In addition to acidity, autochthonous yeast growth is strongly influenced by the temperature and by competition for carbohydrates and nitrogen sources (De Vuyst et al., 2009). In the sourdoughs evaluated in this study, at the end of fermentation, the yeast cell density showed a strong and negative correlation with the maltose concentration $(r=0.92)$ in the doughs fermented by homofermentative LAB ( $L$. acidophilus, L. amylovorus, L. bulgaricus, $L$. jhonsonii, P. acidilactici and P. pentosaceus), and with the glucose concentration $(r=$ 0.72) in the doughs with heterofermentative 
and heterofermentative facultative LABs ( $L$. brevis, L. fermentum, L. plantarum, L. reuteri and $L$. sakei). These results indicate that at high concentrations, these carbohydrates decreased yeast growth.

Maltose is a carbohydrate fermented mostly by heterofermentative LABs through the action of maltose phosphorylase (De Vuyst \& Neysens, 2005), whereas only some homofermentative LABs, such as L. jhonsonii, and some yeasts, such as $S$. cerevisiae, are also capable of fermenting maltose (De Vuyst \& Neysens, 2005; Fujisawa, Benno, Yaeshima, \& Mitsuoka, 1992) justifying the negative correlation obtained in doughs with homofermentative LABs.

The doughs with lower maltose concentrations at the end of the fermentation process were fermented by $L$. reuteri and $L$. fermentum (Table 1). These LAB produced intracellular maltose phosphorylase, catalysing maltose phosphorolytic cleavage, producing glucose-1-phosphate and glucose (Guinee, Pudia, \& Farkye, 1993). Despite the low concentration of maltose and fructose (3.69 and $0.98 \mathrm{mg} \mathrm{g}^{-1}$, respectively) in $24 \mathrm{~h}$ (Table 1), the dough with added L. reuteri did not show yeast inhibition (yeast cell density of $2.20 \log$ CFU g-1 in 24 h, Figure 1-h).

Maltose and glucose, as well as maltodextrin, are continuously formed during the fermentation process, due to starch hydrolysis by the amylase enzymes ( $\alpha$-amylase, $\beta$-amylase and glucoamylases) present in wheat flour (Belitz, Grosch, \& Schieberle, 2008; Struyf, Verspreet, \& Courtin, 2016). However, a portion of the sugars released are consumed by LAB and yeasts; therefore, the concentration of carbohydrates in the dough changes continuously (Codinã,
Mironeasa, Voic, \& Mironeasa, 2013). The doughs fermented by $L$. acidophilus, $L$. amylovorus, $L$. brevis, $P$. acidilactici and $P$. pentosaceus showed a gradual increase in the glucose and fructose concentrations until the end of the process, showing that the concentration of these sugars released through starch hydrolysis was higher than that consumed by the microbiota.

During sourdough fermentation, yeasts ferment flour carbohydrates (sucrose, glucose, fructose and maltose), producing carbon dioxide and ethanol. The release of carbon dioxide results in dough expansion (growth) (Guerzoni, Serrazanetti, Vernocchi, \& Gianotti, 2013). In this study, all sourdoughs presented expansion (Table 1), even those with homofermentative $L A B$, indicating the occurrence of the fermentative activity of autochthonous yeast. The dough with added $L$. amylovorus, had the greatest $\mathrm{CO}_{2}$ production of all homofermentative LABs at 12 h of fermentation, reaching $81.25 \%$ expansion (Table 1). This same dough showed $4.02 \mathrm{log}$ CFU g ${ }^{-1}$ yeast cellular density (Figure 1-B) in 6 $\mathrm{h}$ of fermentation, and acetic acid production was not detected. These results could have contributed to $\mathrm{CO}_{2}$ production. However, in $24 \mathrm{~h}$ of fermentation, reductions in yeast cell density and volume were observed up to $\log 2$ and $18.75 \%$, respectively.

Among the fermentative processes evaluated, the dough fermented by $L$. fermentum presented the highest expansion, reaching $100 \%$ in $15 \mathrm{~h}$ of fermentation. However, after this period, the expansion decreased rapidly, reaching $66 \%$ in $18 \mathrm{~h}$ and $33 \%$ in $24 \mathrm{~h}$ of fermentation (Table 1). Similar behaviour was observed in doughs with $L$. acidophilus, $L$. amylovorus, $L$. brevis and $L$. 
plantarum, which might have been caused by the reduction in the yeast cellular density from $12 \mathrm{~h}$ fermentation or gluten solubility, due to the increase in acidity (Corsetti, 2013). These results, along with the TTA and kinetic growth results, indicate excessive fermentation, being necessary to reduce the fermentation time to $12-15 \mathrm{~h}$.

Gluten is a complex protein formed by glutenin and gliadin. Glutenin is a protein that is soluble in weak acids and is responsible for dough strength and elasticity. Gliadin is soluble in alcohol and guarantees the dough's viscosity (Gänzle, Loponen, \& Gobbetti, 2008). During sourdough fermentation, alcohols and acids are produced, favouring a moderate level of gluten hydrolysis. The acidification of the medium increases the intermolecular strength of gluten, causing the unfolding and exposure of the hydrophobic parts of the protein; consequently, the gluten network is partially hydrolysed, forming an emulsion with higher extensibility and lower elasticity (Clarke et al., 2004).

\section{Volatile compounds}

In addition to the alterations in the dough structure, several volatile compounds are formed during fermentation, which are responsible for the aroma and pronounced flavour of the sourdough.

Table 2 shows that after $24 \mathrm{~h}$ of fermentation, from 25 to 45 volatile compounds were found in each sourdough, which varied according the LAB added, agreeing with Ravyts and De Vuyst (2011) and Yan et al. (2019). Alcohols and carboxylic acids were responsible for over $44 \%$ of the total area of the compounds identified (Figure 2). The alcohols varied between $6.54 \%$ and $46.07 \%$ of the total area. 1-Hexanol and 2,3 Butanediol were the main compounds found. The dough made with $L$. sakei showed the smallest percentage area of alcohol (6.54\%, Table 2). This result was due to the high concentration of butanoic acid (71.32\%), which has a rancid butter aroma, found only in this dough. In the remaining doughs, hexanoic, lactic and octanoic acids represented the carboxyl group. Hexanoic and octanoic acids are responsible for sour, fat and cheesy aromas, while lactic acid presents an unpleasant odour (Siepmann et al., 2019). 


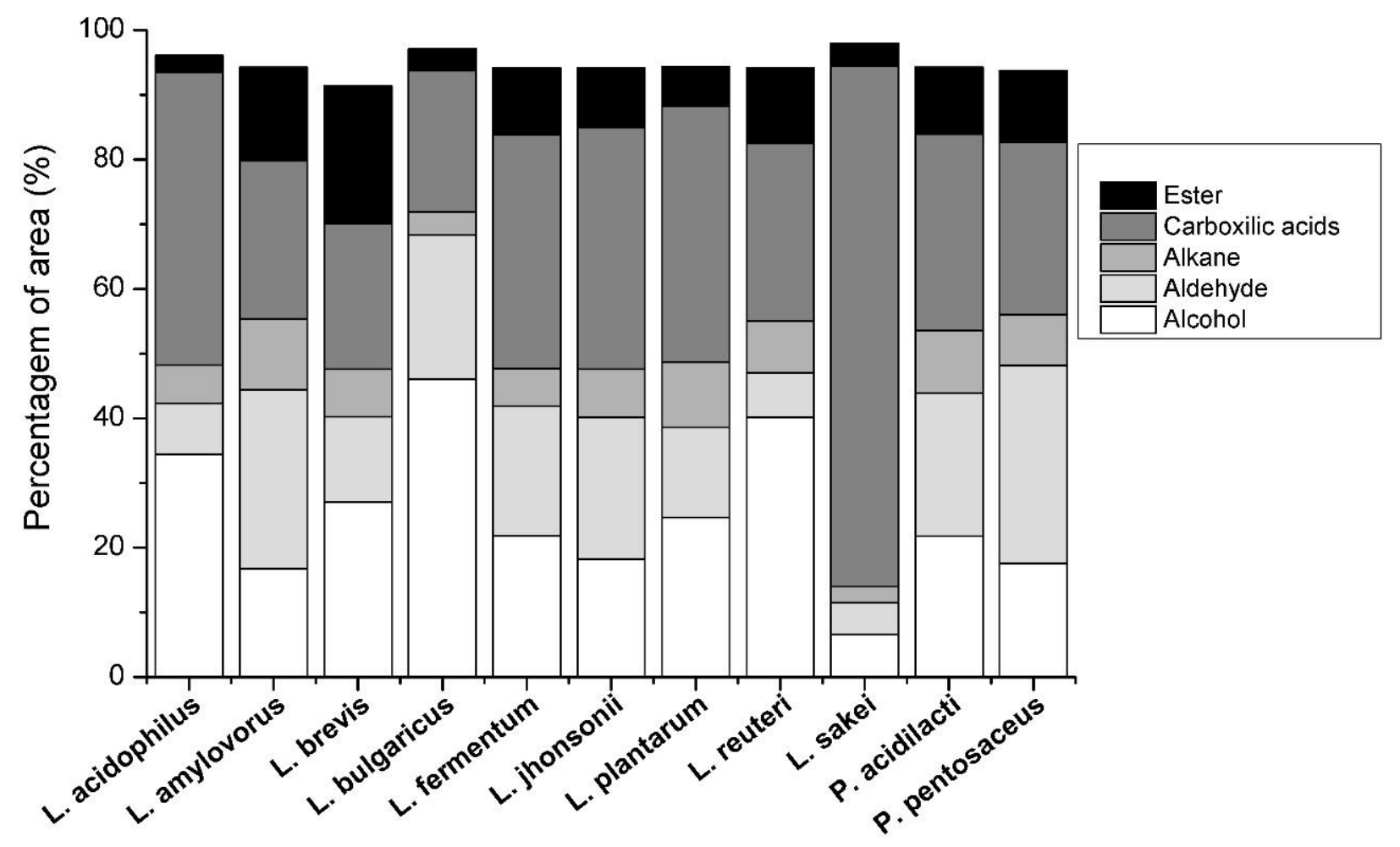

Figure 2. Percentage area of the main chemical classes found after $24 \mathrm{~h}$ of fermentation of type II sourdough. Black histogram: ester; black grey histogram: carboxylic acid; grey histogram: alkane; grey light histogram: aldehyde; white histogram: alcohol.

Apart from alcohols and carboxyl acids, compounds in the ester family are essential to the sourdough aroma, since they contribute its fruity and flowery components. Hexadecanoic acid ethyl ester and linoleic ethyl ester were found in all the doughs after $12 \mathrm{~h}$ of fermentation (results not shown). The dough fermented by $L$. brevis presented the largest ester area (21.27\%), and 2-pentenoic acid, 3,4-dimethyl- ethyl ester was the representative compound $(8.25 \%)$, characterized by a fruity aroma (Table 2 and Figure 2). Moreover, L. brevis has been reported as one of the most frequently found bacteria in naturally fermented doughs, showing suitable adaptation to the sourdough (Corsetti et al., 2001; Siepmann et al., 2018). 


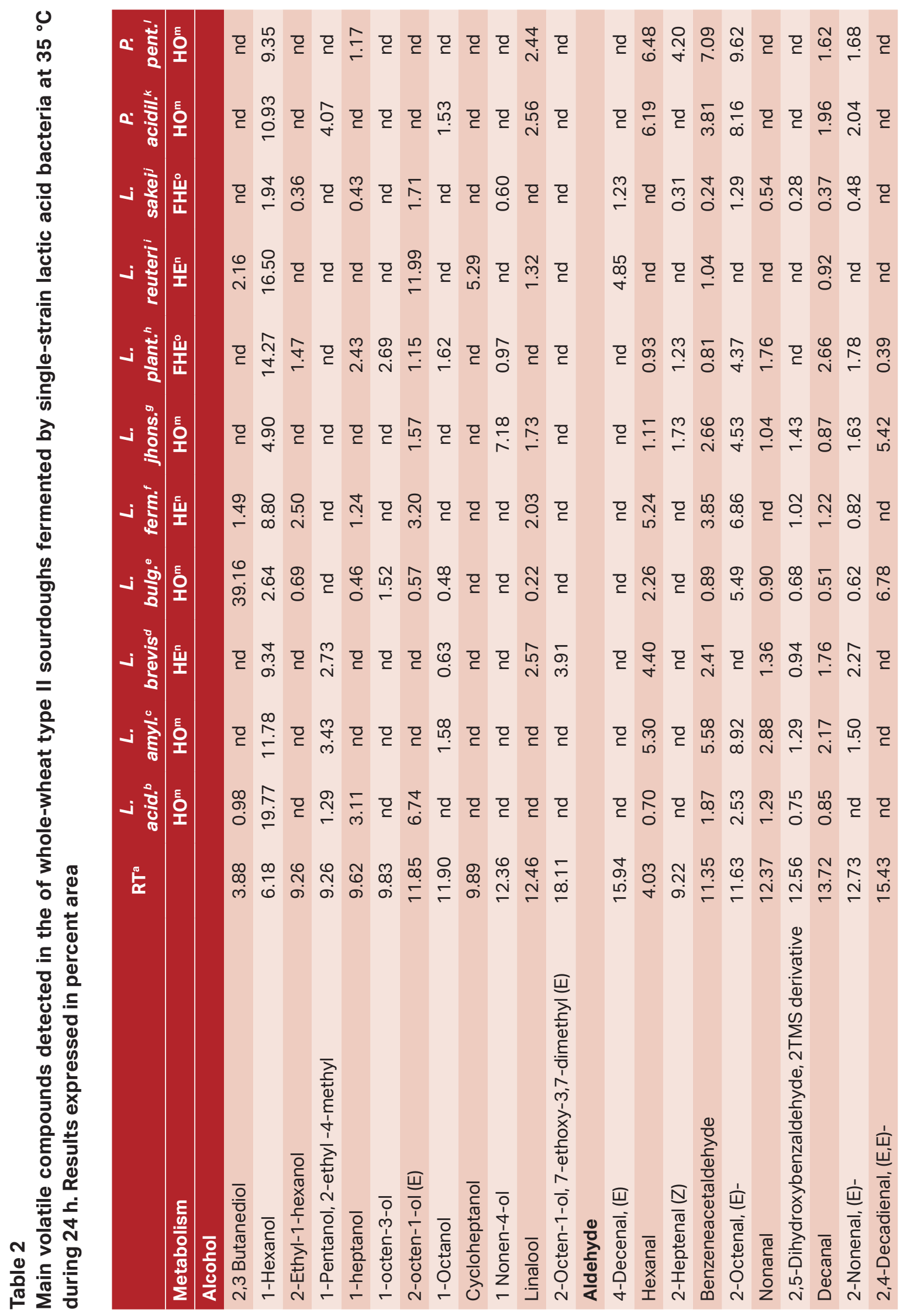




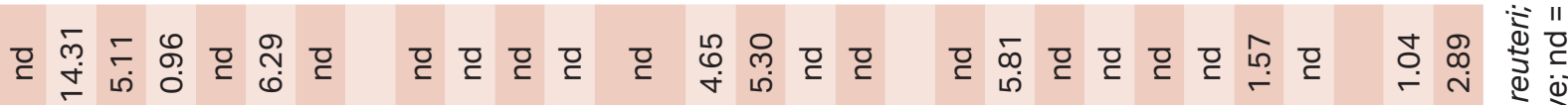

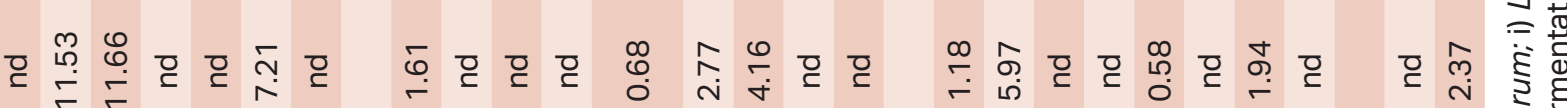

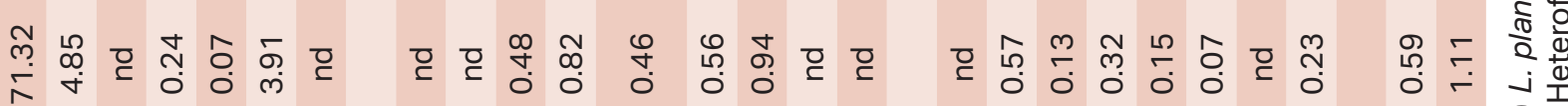

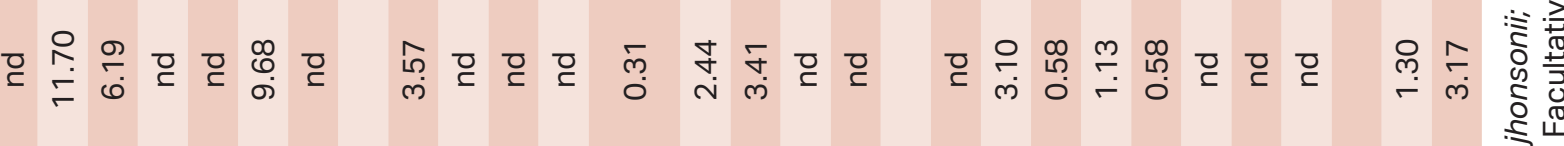

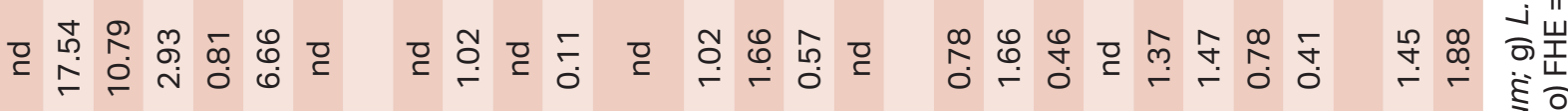

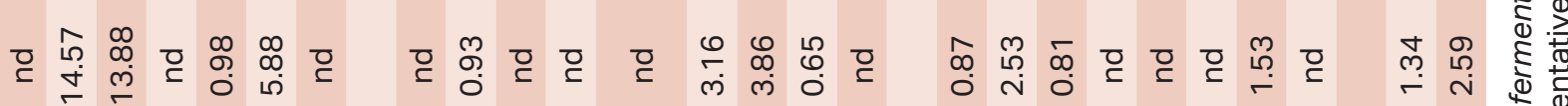

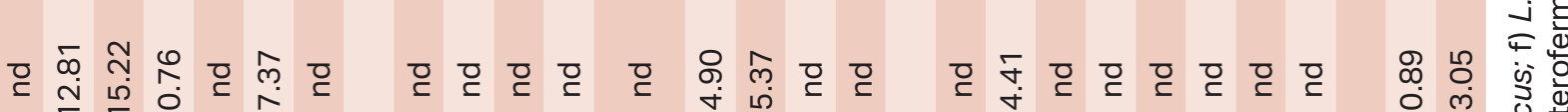

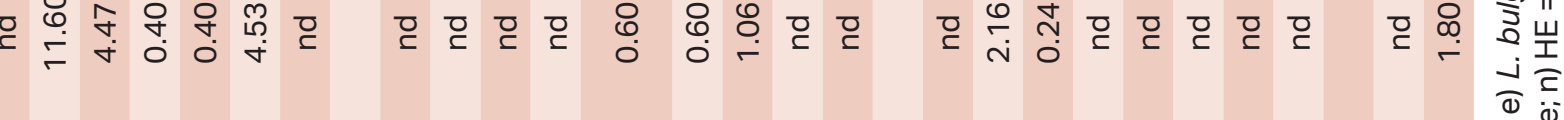

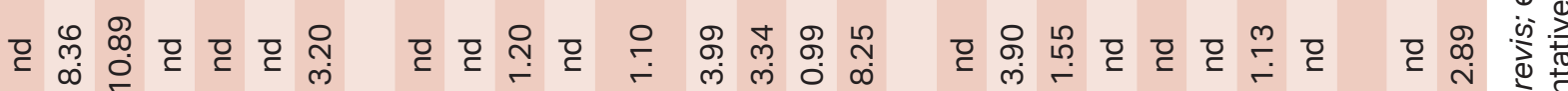
을

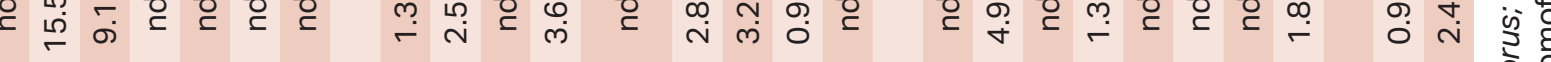

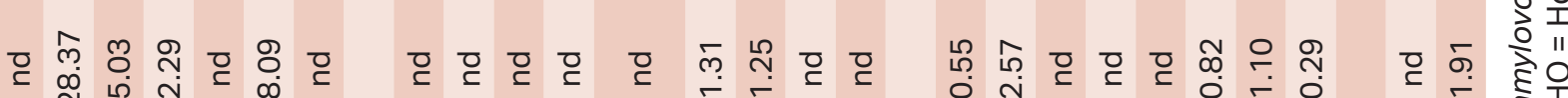

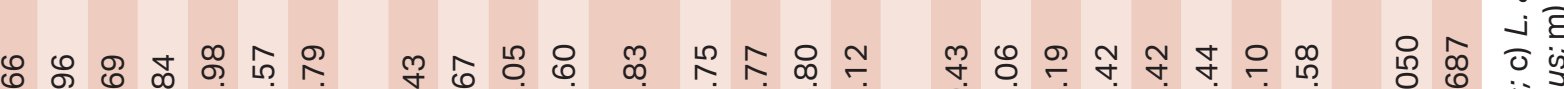
लं

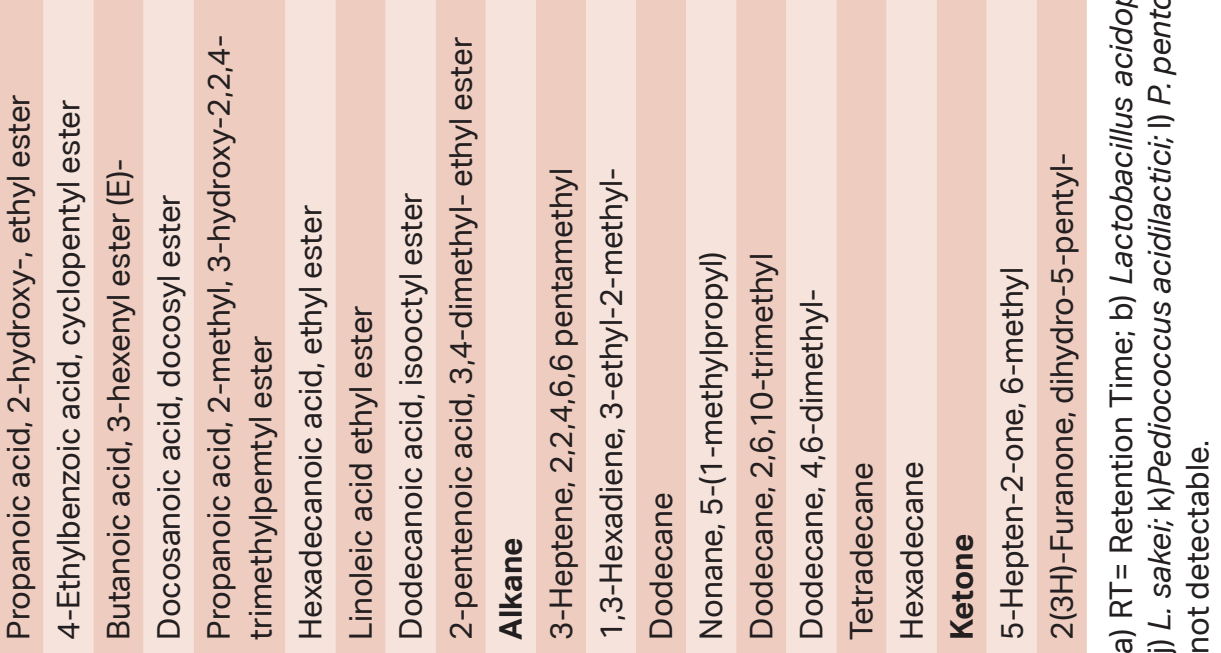


The doughs fermented by $L$. amylovorus, $L$. fermentum, $L$. reuteri, $P$. acidilactici and $P$. pentosaceus also showed high ester areas $(24.45 \%, 10.27 \%, 11.63 \%$, $10.32 \%$ and $11.63 \%$, respectively, Figure 2). Although L. fermentum and $P$. acidilactici presented a large carboxylic acid area (36.16\% and $30.40 \%$, respectively, Figure 2), these LAB promoted excessive acidity in the dough. The high acidity might have contributed to the reduction in the cellular density of the yeasts present in these doughs, whereas the doughs with lower ester area percentages were those fermented by $L$. acidophilus (2.56\%), L. bulgaricus (3.32\%) and L. sakei (3.52\%). These results can be explained by the high percentage areas found for the carboxyl acids and alcohols in these doughs.

\section{Conclusions}

This study showed that the lactic acid bacteria added in the beginning of fermentation influence yeast autochthonous growth and the technologic features of type II sourdough.

L. amylovorus, $L$. brevis and $P$. pentosaceus were notable for the production of doughswith goodaromatic features, suitable production of esters, a low concentration of alcohols and carboxylic acids and without the formation of undesirable compounds. $L$. reuteri had the best performance in sourdough fermentation, achieving the ideal FQ value without inhibiting yeast growth and showing a good volatile compound profile.

This study contributes to the management of desirable characteristics of type II sourdough by the selection of a starter culture. Suggestions for future work would be the characterisation of the microbiota present at the end of fermentation and the study of sourdough production with fermentation in co-culture.

\section{Acknowledgements}

The authors thank the Coordination for the Improvement of Higher Education Personnel for the scholarship and the Agricultural Research Service Culture Collection for stirpes donation.

\section{Conflict of Interest}

The authors have no conflicts of interest.

\section{References}

Alfonzo, A., Miceli, C., Nasca, A., Franciosi, E., Ventimiglia, G., Di Gerlando, R., Tuohy, K., Francesca,N., Moschetti, G., Settanni, L. (2017). Monitoring of wheat lactic acid bacteria from the field until the first step of dough fermentation. Food Microbiology, 62(1), 256-269. doi: 10.1016/j.fm.2016.10.014

Belitz, H. D., Grosch, W., \& Schieberle, P. (2008). Food chemistry (vol. 6). Heidelberg: Springers.

Cappelle, L. Guylaine, M. Gänzle, \& M. (2013). Gobbetti. History and Social Aspects of Sourdough In M. Gobbetti, \& M. Gänzle (Eds.), Handbook on sourdough biotechnology (vol. 1, pp.1-10). Boston: Springer. doi: 10.1007/978-1-4614-54 25-0 
Clarke, I. C., Schober, J. T., Dockery, P., O'Sullivan, K., \& Arendt, K. E. (2004). Wheat sourdough fermentation: effects of time and acidification on fundamental rheological properties. Cereal Chemistry, 81(3), 409-417. doi: 10.1094/ CCHEM.2004.81.3.409

Codinã, G. G., Mironeasa, S., Voic, D. V., \& Mironeasa, C. (2013). Multivariate analysis of wheat flour dough sugars, gas production, and dough development at different fermentation times. Czech Journal of Food Science, 31(1), 222-229. doi: 10.17221/216/2012-CJFS

Corsetti, A. (2013). Technology of sourdough fermentation and sourdough appplications. In M. Gobbetti, \& M. Gänzle (Eds.), Handbook on sourdough biotechnology (vol. 1, pp.85-103). Boston: Springer. doi: 10.1007/978-1-4614-54 25-0

Corsetti, A., Gobbetti, M., Balestrieri, F., Paoletti, F., Russi, L., \& Rossi, J. (1998). Sourdough lactic acid bacteria effects on bread firmness and staling. Journal of Food Science, 68(2), 347-351. doi: 10.1111/j. 1365-2621.1998.tb15739.x

Corsetti, A., Lavermicocca, P., Morea, M., Baruzzi, F., Tostic, N., \& Gobbetti, M. (2001). Phenotypic and molecular identification and clustering of lactic acid bacteria and yeasts from wheat (species Triticum durum and Triticum aestivum) sourdoughs of Southern Italy. International Journal of Food Microbiology, 64(1-2), 95-104. doi: 10.1016/s0168-1605(00)00447-5

De Vuyst, L., \& Neysens, P. (2005). The sourdough microflora: biodiversity and metabolic interactions. Trends in Food
Science \& Technology, 16(1-3), 43-56. doi: 10.1016/j.tifs.2004.02.012

De Vuyst, L., Vrancken, G., Ravyts, F., Rimaux, T., \& Weckx, S. (2009). Biodiversity, ecological determinants, and metabolic exploitation of sourdough microbiota. Food Microbiology, 26(7), 666-675. doi: 10.1016/j.fm.2009.07.012.

Decock, P., \& Cappelle, S. (2005). Bread technology and sourdough technology. Trends in Food Science \& Technology, 16(1-3), 113-120. doi: 10.1016/j.tifs.2004. 04.012

Demirbaş, F., İspirli, H., Kurnaz, A. A., Yilmaz, M. T., \& Dertli, E. (2017). Antimicrobial and functional properties of lactic acid bacteria isolated from sourdoughs. LWT Food Science and Technology, 79(1), 361366. doi: 10.1016/j.Iwt.2017.01.067

Esteve, C. C., De Barber, C. B., \& MartínezAnaya, M. A.Esteve, C. C., De Barber, C. B., \& Martínez-Anaya, M. A. (1994). Microbial sour doughs influence acidification properties and breadmaking potential of wheat dough. Journal of Food Science, 59(3) 629-633. doi: 10.1111/j.1365-26 21.1994.tb05579.x

Fujisawa, T., Benno, Y., Yaeshima, T., \& Mitsuoka, T. (1992). Taxonomic study of the Lactobacillus acidophilus group, with recognition of Lactobacillus gallinarum sp. nov. and Lactobacillus johnsonii sp. nov. and synonymy of Lactobacillus acidophilus group A3 (Johnson et al. 1980) with the type strain of Lactobacillus amylovorus (Nakamura 1981). International Journal Systematic Bacteriology, 42(3), 487-491. doi: 10.10 99/00207713-42-3-487 
Fuwa, H. A. (1954). A new method for microdetermonation of amylase activity by the use of amylase as the substrate. The Journal of Biochemistry, 41(5), 583603. doi: 10.1093/oxfordjournals.jbchem. a126476

Gaglio, R., Barbera, M., Tesoriere, L., Osimani, A., Busetta, G., Matraxia, M., Attanzio, A., Restivo, I., Aquilanti, L., Settanni, L. (2021). Sourdough "ciabatta" bread enriched with powdered insects: physicochemical, microbiological, and simulated intestinal digesta functional properties. Innovative Food Science and Emerging Technologies, 72(1), 102755. doi: 10.1016/j.ifset.2021.102755

Gänzle, M. G., Ehmann, M., \& Hammes, P. W. (1998). Modeling of growth of Lactobacillus sanfranciscensis and Candida milleri in response to process parameters of sourdough fermentation. Applied and Environmental Microbiology, 64(7), 2616-2623. doi:10.1128/AEM.64.7. 2616-2623.1998

Gänzle, M. G., Loponen, J., \& Gobbetti, M. (2008). Proteolysis in sourdough fermentations: mechanisms and potential for improved bread quality. Trends in Food Science \& Technology, 19(10), 513-521. doi: 10. 1016/j.tifs.2008.04.002

Guerzoni, M. E., Serrazanetti, D. I., Vernocchi, P., \& Gianotti, A. (2013). Physiology and biochemistry of sourdough yeasts. In M. Gobbetti, \& M. Gänzle (Eds.), Handbook on sourdough biotechnology (pp. 155-181). Boston: Springer.

Guinee, T. P., Pudia, P. D., \& Farkye, N. Y. (1993). Fresh acid-curd cheese varieties. In $P$. F. Fox (Ed.), Cheese Chemistry, Physics and Microbiology (vol. 2, pp. 363-419). London: Chapman \& Hall.

Hammes, W. P., \& Gänzle, M. G. (1998). Sourdough bread and related products. In B. J. B. Wood (Ed.), Microbiology of fermented foods (vol. 1, pp. 199-216). Boston: Springer.

Hammes, W. P., \& Vogel, R. F. (1995). The genus Lactobacillus. In B. J. B. Wood, \& W. H. Holzapfel (Eds.), The genera of lactic acid bacteria (pp. 19-54). Boston: Springer.

Huys, G., Daniel, H.-M., \& De Vuyst, L. (2013). Taxonomy and biodiversity of sourdough yeasts and lactic acid bacteria. In $\mathrm{M}$. Gobbetti, \& M. Gänzle (Eds.), Handbook on sourdough biotechnology. (pp. 105-154). Boston: Springer.

Lazo-Vélez, M. A., Garzon, R., Guardado-Félix, D., Serna-Saldivar, S. O., \& Rosell, C. M. (2021). Selenized chickpea sourdoughs for the enrichment of breads. LWT - Food Science and Technology, 150(1), 112082112030. doi: 10.1016/j.Iwt.2021.112082

Manini, F., Casiraghi, M. C., Poutanen, K., Brasca, M., Erba, D., \& Plumed-Ferrer, C. (2016). Characterization of lactic acid bacteria isolated from wheat bran sourdough. LWT - Food Science and Technology, 66(1), 275-283. doi: 10.1016/j.lwt.2015.10.045

Narendranath, N.V., Thomas, K.C., \& Ingledew, W.M. (2001)Effects of acetic acid and lactic acid on the growth of Saccharomyces cerevisiae in a minimal medium. Journal of Industrial Microbiology \& Biotechnology, 26(3), 171-177. doi: 10.1038/sj/jim/7000 090

Nionelli, L., Curri, N., Curiel, J. A., Di Cagno, R., Pontonio, E., Cavoski, I., Gobbetti, 
M., Rizzello, C. G. (2014). Exploitation of Albanian wheat cultivars: characterization of the flours and lactic acid bacteria microbiota, and selection of starters for sourdough fermentation. Food Microbiology, 44(1), 96-107. doi: 10.10 16/j.fm.2014.05.011

Poutanen, K., Flander, L., \& Katina, K. (2009). Sourdough and cereal fermentation in a nutritional perspective. Food Microbiology, 26(7), 693-699. doi: 10.10 16/j.fm.2009.07.011

Ravyts, F., \& De Vuyst, L. (2011). Prevalence and impact of single-strain starter cultures of lactic acid bacteria on metabolite formation in sourdough. Food Microbiology, 28(6), 1129-1139. doi: 10. 1016/j.fm.2011.03.004

Reale, A., Di Renzo, T., Preziuso, M., Panfili, G., Cipriano, L., \& Messia, M. C. (2019). Stabilization of sourdough starter by spray drying technique: New breadmaking perspective. LWT - Food Science and Technology, 99(1), 468-475. doi: 10.1016/j. Iwt.2018.10.016

Ripari, V., Gänzle, M. G., \& Berardi, E. (2016). Evolution of sourdough microbiota in spontaneous sourdoughs started with different plant materials. International Journal of Food Microbiology, 232, 35-42. doi: 10.1016/j.ijfoodmicro.2016.05.025

Sajdakowska, M., Gębski, J., ŻakowskaBiemans, S., \& Jeżewska-Zychowicz, M. (2019). Willingness to eat bread with health benefits: habits, taste and health in bread choice. Public Health, 167(1), 7887. doi: 10.1016/j.puhe.2018.10.018

Siepmann, F. B., Almeida, B. S. de, Ripari, V., Silva, B. J. G. da, Peralta-Zamora, P. G.,
Waszczynskyj, N., \& Spier, M. R. (2019). Brazilian sourdough: microbiological, structural, and technological evolution. European Food Research and Technology, 245(2), 1-12. doi: 10.1007/s00217-01903254-8

Siepmann, F. B., Ripari, V., Waszczynskyj, N., \& Spier, M. R. (2018). Overview of sourdough technology: from production to marketing. Food and Bioprocess Technology, 11(2), 242-270. doi: 10.1007/ s11947-017-1968-2

Struyf, N., Verspreet, J., \& Courtin, M. C. (2016). The effect of amylolytic activity and substrate availability on sugarrelease in non-yeasted dough. Journal of Cereal Science, 69(1), 111-118. doi: 10.1016/j. jcs.2016. 02.016

Swiegers, J., Bartowscky, E., Henscke, P., \& Pretorius, I. (2005). Yeast and bacterial modulation of wine aroma and flavour. Australian Journal Grape Wine and Research, 11(2), 139-173. doi: 10.1111/ j.1755-0238.2005.tb00285.x

Vernon-Carter, E. J., Garcia-Diaz, S., Reyes, I., Carrillo-Navas, H., \& Alvarez-Ramirez, J. (2017). Rheological and thermal properties of dough and textural and microstructural characteristics of bread with pulque as leavening agent. International Journal of Gastronomy and Food Science, 9(1), 3948. doi: 10.1016/j.ijgfs.2017.03.001

Wang, Y. H., Yang, Y. Y., Li, H. Q., Zhang, Q. D., Xu, F., \& Li, Z. J. (2021). Characterization of aroma-active compounds in steamed breads fermented with Chinese traditional sourdough. LWT- Food Science and Technology, 152(1), 112347. doi: 10.10 16/j.lwt.2021.112347 
Yan, B., Sadiq, F. A., Cai, Y., Fan, D., Chen, W., Zhang, H., \& Zhao, J. (2019). Microbial diversity in traditional type I sourdough and jiaozi and its influence on volatiles in Chinese steamed bread. LWT -Food Science and Technology, 101(1), 764773. doi: 10.1016/j.Iwt.2018.12.004 